\section{O INSTANTE SÓCIO-POLÍTICO E AS "INSTITUIÇÕES" DE OLIVEIRA VIANA}

\section{Amadeu de Oliveira Freitas}

O hábito de encarar sempre a disjunção entre os recursos humanos e as dificuldades telúricas, relativamente à dominação do espaço brasileiro, impõe a indispensável serenidade, para o exame de nossos problemas sociais.

O fator demográfico face ao fator fisiográfico, as limitaçôes qualitativas e quantitativas daquele e os óbices ecológicos dêste, explicam com ou sem o auxílio de tantas meias-verdades das escolas sociológicas, as nossas deficiências político-sociais. São temas de equação nacional, que independem de discussões metodológicas, pois as conseqüências de seu encontro ressaltam à luz de palpáveis realidades, que desafiam o engenho da política e da administração nacionais.

Oliveira Viana, tenta, em obra recente, - "Instituições Políticas Brasileiras" - oferecer a solução definitiva das questões que afligem, há tanto, nossas populações.

Os aspectos políticos, o sociólogo os vê, sob os ângulos da República Velha, sem atender às revoluções últimas operadas nos ambientes melhor servidos pelos meios rápidos de comunicações. Por isso, talvez, não se realizem suas profecias, sôbre o fracasso da terceira Constituição. republicana.

Discípulo de Alberto Tôrres, diferencia-se em que "Tôrres, mais filósofo do que sociólogo, pensava num Brasil global", ao passo que Viana não pode compreendê-lo ainda como um "continuum" social.

Parece, entanto, que os dous têm razão - um encarando, com faIhas filosóficas, mas tantas vêzes brilhantemente, a formação e organização nacionais; - outro tendendo ao levantamento sociológico do. país, pelos métodos monográficos de Le Play, corrigidos pelas críticas de Gusti, da escola rumena. Ambos, porém, visando um plano de reorganização em profundidade, para adaptar as instituições às realidades. nacionais, pela "centralização desconcentrada" atendendo às diferen-. ciações regionais.
Aplicando ao historicismo sociológico, em que ambos embasam suas elucubrações, o complemento duma "concepção sistemática da história como processo humano, realizando-se por fôrças imanentes, unificadas na racionalidade, vindo de um princípio e tendendo para um fim transcendente e absoluto", as conclusões econômicas de Tôrres, inteiramente aproveitáveis, completar-se-iam, eventualmente, com os atuais corretivos político-administrativos de Oliveira Viana.

Repetindo, como bom e sábio mestre, os conceitos de "Populações Meridionais", desde 1924, sustenta Oliveira Viana que a célula do organismo nacional é "o clan", caracterìsticamente rural, que age e reage sôbre os dois terços de nossas populações.

Diz êle: "Note-se ainda que o "oikos" feudal, de economia oniprodutiva, que vimos constituir-se, durante o período colonial, nas zonas do litoral e de faixa costeira desde o tempo de Vieira, que tornava "cada família uma república - ainda subsiste, na sua plenitude primitiva, nas fazendas pastoris..." de certas zonas longínquas, surgindo em São Paulo e Pernambuco os contrastes da rotina agrária ao lado de progressos megalotécnicos e capitalísticos, o que faz do Brasil um "melting-pot" sociológico.

Sua preocupação máxima, porém, é o "espírito de clan" que a nossa formação rural infundiu na estrutura social. Com sua fôrça é que não contaram, a seu ver, os teóricos e constitucionalistas do Império e da República.

A correção do "espírito de clan" só julga possível pelo poder imparcial do govêrno central, outrora representado pelo poder moderador ou pessoal de Pedro II.

Neste passo demonstra exaustivamente nossas diferenças culturais dos ânglo-saxões e até dos russos, todos socialmente amparados nas comunidades de aldeia, hoje, violentados neste último país em sua evolução pela tirania vermelha.

Demonstrando a inanidade, segundo Robert Lyne, das instituições exóticas informa que os sovietes não eliminaram as desigualdades de classes, existentes na sociedade russa - pois há uma profunda separação, "cada vez mais crescente", entre o Kremlin e o resto da Rússia. Os efeitos das desigualdades ressaltam, pelo ressurgimento, como homens excepcionais, de técnicos, administradores, cientistas e peritos, pagos com salários excepcionais e tendo também poderes excepcionais sôbre os demais".

Daí a continuação do fracasso do Sovietismo também em outros setores, apesar de realizaçōes materiais apreciáveis. A luta pela transformação do localismo tribal ou do comunarismo de aldeia em comunarismo de Nação, já se vinha processando pela ação opressora do próprio Czarismo. Tenta mudar as condições exteriores para conseguir a transformação das condições interiores ("imanentes") da cultura, es- 
quecendo-se das reações naturais e universais de personalidade humana.

Mas é justamente o homem, na sua expressão civil e política, a quem pretende Oliveira Viana proteger definitivamente, combatendo os "utopismos dos Pimenta Bueno, Barbalho, Cavalcanti e Rui", de quem exalta, entanto, a obra imperecível de cimentação do poder judi. ciário, como base institucional da verdadeira democracia.

Esta, porém, na opinião do sociólogo fluminense, não vingará no país, por via dos partidos, apesar dos progressos dos serviços e leis sociais e militares.

O regime de "clan", que vigora também em várias regiões européias e civilizadas, não nos deve, pois, envergonhar, apesar de agravado. em nosso ambiente social. Releva notar, porém, que precisa ser substituído, porque inutiliza grandemente a eficiência partidária, pondo a serviço de seus egoísmos a justiça e a polícia, especialmente nos imensos confins rurais, onde se capilarisa, fundamentalmente, a trama social.

"Dêsses povos que admiramos, diz, como o americano a um inglês - um estudo mais atento de sua história mostrará que a sua grandeza vem da iniciativa privada - da ação de seus agricultores, dos seus industriais, dos seus comerciantes, dos seus educadores, dos seus cientistas, das suas escolas e Universidades, em primeiro lugar - e, só em segundo lugar, da ação do Estado e dos políticos".

E acrescenta, mais além, com amargo pessimismo: "Já o disse em outro volume: "Os partidos políticos, pelo menos no Brasil, munca puderam representar o papel de agentes de formação desta mentalidade solidarista, de tipo altruísta, a que me venho referindo - isto porque foram sempre agrupamentos constituídos para a satisfação de ambições pessoais e não para a realização de interêsses coletivos e públicos, isto é, relativos ao bem comum de uma "classe", de um "município", de uma "província ou da Nação". A seu ver, nêles predomina o "interêsse individual (pessoal, de família ou de clã); só é possível de ser realizado, entretanto, através do grupo ou do partido." Tudo como na fórmula de Stirner: "O grupo não se possui; tu é quem possui o grupo. e dêle te serves".

Entretanto, prega o sociólogo o direito de voto ao homem socializado, ao homem sindicalizado, apesar da lentidão facultativa dos sindicatos rurais, em país das características do nosso.

Para protegê-los, só pela libertação da justiça e da política dos atos regionais ou locais, apesar de que justiça e polícia muito mellhoraram, ùltimamente, pelo menos no sul. E diz: "Insisto: o nosso grande problema na organização da democracia no Brasil - problema funda. mental, para o qual devemos convergir todo o esfôrço e tôda a combatividade de nosso idealismo - não é a generalização do sufrágio, não é o sufrágio universal; é - a organização da liberdade civil e indivi. dual. Reconhecer, assegurar e organizar a defesa efetiva das liberdades civis do povo-massa há de ser o nosso primeiro trabalho - se sonhamos dar vida e realidade à democracia no Brasil. E' êste o meio principal, e talvez único, que temos para desintegrar os nossos dois formidáveis e velhos complexos - o do "feudo" e o do "clä" - que nasceram e se desenvolveram justamente em conseqüência do regime quadrissecular de desgarantias dessas liberdades privadas, em que tem vivido o nosso povo-massa desde o I século - como vimos em Populações Meridionais (cap. IX, X, XI e XII).

Desta fase de insegurança e precariedade das liberdades civis $e$ individuais e suas garantias, que nos, vem da Colônia, restam ainda, entretanto, duas reminiscências vivazes, que são como dois anacronis mos, que ainda resistem, apoiados pelas quatro patas nos pequenino interêsses da politicalha de província - pequeninos e mesquinhos; mas, mais poderosos, ao que parece, do que os interêsses superiores da Justiça, do Direito e da própria Liberdade. Estas reminiscências coloniais são:

a) a justiça estadual (o juiz "nosso") ;

b) a polícia política (o delegado "nosso").

Esses mesquinhos e pequeninos interêsses da politicalha da província - recobrindo e dissimulando o seu egoísmo com o manto dos. "sagrados princípios do regime federativo" e das "liberdades locais" - é que não nos permitiram ainda - e tão cedo não permitirão instituir e organizar êstes dois corretivos garantidores e saneadores

a) a justiça federalizada - na dignidade da sua expressão na. cional;

b) a polícia de carreira - também federalizada, integralmente garantida como uma nova magistratura e, destarte, liberta dos "coronéis de aldeia", dos "partidos do govêrno" e das oligarquias oniponéis de aldeia, dos independente, servindo aos interêsses gerais e impessoais da ordem pública e da ordem jurídica das pequenas comunidades locais".

A unidade processual será, talvez, o passo preambular para a unidade administrativa da magistratura e da polícia, se a evolução da maioria dos partidos não se processar no sentido altruístico, que remaioria dos partio. Seus choques se agravarão justamente no ambiente judiciário e policial, suspirando essas mesmas instituições pela sua superposição aos ambientes regionais.

Nesse rumo se processa a evolução do ensino universitário, entre nós, que espera mais compreensão e recursos de parte do poder federal.

Sua eficiêncía será elemento decisivo na formação das elites e ma melhora do funcionamento de tôdas as instituições nacionais.

A difusão da instrução primária, rural e técnica é, porém, igual mente um fator basilar no corretivo ao espírito de clan. Ela incenti. vada pela assistência sanitária, transporte e energia é que possibili. 
tará uma consciência cívica capaz de evitar o desaparecimento da polícia e da justiça, em face do poder dissolvente dos clãs partidários, dominantes ainda em vastas extensões territoriais do país.

Insiste ainda o sociólogo na aplicação de regimes administrativos peculiares para as diferentes regióes da Federação:

"Os velhos administradores do período colonial, sempre tão realistas e objetivos, já haviam sentido esta diversidade: - e a haviam atendido com soluções adequadas. Quem quer que estude a história da nossa administração local na Colônia, verá, com efeito, que - nos Regimentos outorgados pela Metrópole - as atribuiçóes conferidas aos governadores de capitanias não guardavam uniformidade; ao contrário, eram, ora ampliadas, ora restringidas, conforme a situação econômica, social ou política de cada capitania ou mesmo o grau de confiança ou capacidade do delegado.

E' o que conviria pleitear como sistema ideal para o Brasil neste setor: - e só assim a descentralização federalista seria razoável. 0 mal do federalismo não está na sua descentralização; está antes na sua uniformidade. Rui, com a sua Constituição descentralizadora, não quis instituir esta desigualdade para os Estados. E' que não o permitia o modêlo americano então em voga (não o permitia para os Estados, note-se, embora o permitisse para os municípios).

E' claro que da Constituição de 91, por êle elaborada e assim descentralizada, tinha que resultar o que resultou: as oligarquias. $E^{\prime}$ certo que - com os olhos postos na democracia americana - vivemos a deblaterar contra elas; mas, sem grande justiça - porque as oligarquias não são senão a nossa vernaculíssima instituição do clã eleitoral, estendida a uma área mais ampla do que o feudo ou o município: - a uma província ou Estado. São legítimas expressões culturais do nosso Direito Público Costumeiro - do direito público do povo-massa. Pelas condicões dentro das quais se processou a nossa formação política, estamos condenados às oligarquias: - e, felizmente, as oligarquias existem. Pode parecer paradoxo; mas, numa democracia como a nossa, elas têm sido a nossa salvação. O nosso grande problema, como já disse alhures, não é acabar com as oligarquias; é transformá-las - fazendo-as passarem da sua atual condição de oligarquias broncas para uma nova condição - de oligarquias esclarecidas. Estas oligarquias esclarecidas seriam então, realmente, a expressão da única forma de democracia possível no Brasil; porque realizada na sua forma genuína, isto é, no sentido ateniense - do govêrno dos melhores".

Nota-se que Oliveira Viana absolutamente não confia nos efeitos do sufrágio secreto e universal, exigindo uma proteção federal onímoda aos direitos civis como base das conquistas políticas pessoais e regionais definitivas.
Seria, talvez, a complementação evolucional e progressiva da po. Lítica e da administração do país, nesses últimos anos.

A próxima sucessão presidencial dará, quiçá, razão ao ilustre fluminense. Nela estão em jôgo o funcionamento dos partidos e a ação tutelar do poder presidencial da República.

Se aquêles falharem ao seu destino sociológico, o executivo fedict catecismo cívico as "Instituições Brasileiras", de F. J. de Oliveira Viana. 